\title{
Genetic Architecture for Yield and Contributing Components in Rice (Oryza sativa L.) under Salt Affected Soil
}

\author{
Raushan Lal ${ }^{{ }^{*}}$, O. P. Verma ${ }^{2}$, Manoj Kumar ${ }^{3}$, Neeta Tripathi ${ }^{2}$ and A. K. Sharan ${ }^{4}$ \\ ${ }^{1}$ Department of Agriculture, Kamla Nehru Institute of Physical and Social Sciences, \\ Sultanpur, Uttar Pradesh, India \\ ${ }^{2}$ Department of Genetics and Plant Breeding, Narendra Deva University of Agriculture and \\ Technology, Kumarganj, Ayodhya, Uttar Pradesh, India \\ ${ }^{3}$ Central Potato research Institute, Shimla, Himachal Pardesh, India \\ ${ }^{4}$ Department of Botany, Nalanda Open University, Patna, Bihar, India \\ *Corresponding author
}

\section{A B S T R A C T}

The experiment was conducted at GPB research Farm of N.D University of Agriculture and Technology, Kumarganj, Ayodhya. Set of two experiment carried over in two season of year 2014 and 2015 respectively. Thirty

Keywords

Check, RBD,

heritability, path analysis

Article Info

Accepted:

20 June 2021

Available Online:

10 July 2021 genotypes and two checks were evaluated in experiment number one by RBD fashion and three replications while in experiment number two crossing occurred among twenty lines and three testers. The data analysed by ANOVA to analysis of variance for Randomized block design, coefficient of variation, heritability and genetic advance, correlation coefficients, path coefficients analysis Krishnamurthy and Kumar, combining ability analysis and heterosis over better-parent and standard variety. In general, PVC were higher than the GCV for all characters under the salt affected indicates influence of environment. In the current investigation path analysis identified biological yield per plant and harvest index as most important direct yield contributing traits in both the experiments. SCA variances were higher than GCA variances for all the characters indicating presence of non-additive gene action.

\section{Introduction}

Rice (Oryza sativa L.) is a crop plant belong to the family of grasses, Gramineae (poaceae). It is one of the major food crop of the world and form the staple diet of about half of the world's population. Salt affected areas have increased day by day because of excessive use of irrigation water with improper drainage coupled with the poor quality irrigation water. High yielding rice varieties (Shama et al.,) for salinity resistance is a gift for mankind to face 
this viscous problem. Information on general and specific combining ability for yield and its components will prove very useful in selection of appropriate parents for the development of superior hybrids. The choice of parents especially for heterosis (Krishna et al., 2011) breeding largely depends upon their combining ability and mean performance. The study of combining ability (Parsad et al., 2019) gives useful information in selection of parental line and devising appropriate breeding strategies. The identification of important yield contributing characters out of the numerous plant traits is necessary because it would be impossible and impractical to concentrate and work on improving many characters at a time. The correlations and path coefficient analysis (Krishnamurthy and kumar, 2012) help us in identification of important yield contributing characters. The success of China in achieving another quantum jump in yield status of rice through development and exploitation of highly yielding hybrid varieties has encouraged us to make attempts in this directions. Three line method or CMS system which is possible and has been found to be most effective genetic tool for developing hybrids, (b) two line method or PGMS and TGMS system, and (c) one line system or apomictic system. The CGMS is essentially CMS with a provision of fertility restoration by nuclear gene (s).

Present investigation "Genetic architecture for yield and its contributing components in rice (Oryza Sativa L.) under salt affected soil" is proposed to be under taken with the following objectives:

To examine the genetic variability and evaluate the lines of various traits in rice genotypes.

To compute association studies at genotypic and phenotypic levels among different characters.
To study the combining ability variances and their effects.

To find out gene action involved in the inheritance of various characters.

To estimates heterosis (Satya et al., 1999) over better parent and standard varieties and

To identify promising parents and superior hybrid for exploitation in breeding program.

\section{Materials and Methods}

The present investigation entitled "Genetics architecture for yield and its contributing components in rice (Oryza sativa L.) under salt affected soil" was conducted at Genetics and plant breeding Research Farm of N.D university of Agriculture and Technology, Kumarganj, Ayodhya. The crosses were made during Kharif 2014and crosses along with parental lines and check variety were evaluated during Kharif, 2015.

In experiment $\mathrm{I}$, the thirty diverse genotypes (Mahto et al., 2003). Along with (two checks viz. Narendra Usar 3 and IR 28) of rice were evaluated in randomised block design (table1) with three replications during kharif 2015.

In experiment II, the line $\times$ tester (Arunachalam, 1974) set of 60 hybrids (F1s) derived by crossing 20 lines (females) with three higher yielding testers (male) viz. NDR 359, Narendra Usar 2009 and Narendra Usar 3 during kharif 2014.

The $60 \mathrm{~F} 1 \mathrm{~s}$ along with their parents and check varieties (CSR 43 and IR 28) were evaluated in randomised complete block design with three replications during kharif, 2015. The fertilizers were applied @ 120 kg Nitrogen, 60 $\mathrm{kg}$ phosphorus and $60 \mathrm{~kg}$ potash per hectare through urea, DAP and muriate of potash, respectively. 


\section{Results and Discussion}

The mean sum of squares due to treatments were highly significant for all the thirteen characters in both the experiment indicating presence of sufficient variability (Krishnamurthy and Kumar, 2012) in the study materials. Mean sum of square due to replications were found non-significant for all the characters under salt affected soil in both the experiment. Among the parents, minimum and maximum harvest index was recorded in Narendra $2064(36.81 \%)$ and NDRK 50036 (39.00\%), respectively. In crosses, it varied from 37.00 (Pusa Basmati $1 \mathrm{X}$ Narendra Usar 2009) to $43.65 \%$ (NDRK 50045 X NDR 359). The minimum 1000 grain weight was recorded in parents IR 5511079-3B-11-3 (19.27) while maximum in parents Narendra 3112-1 (23.94). Among crosses, it ranged from 19.71 (IR 5511079-3B-11-3 X Narendra Usar 3) to 24.96 (CSR 36 X NDR 359). High estimates of broad sense heritability (>75\%) was recorded for all the character except panicle bearing tillers per plant and panicle length which exhibited moderate estimate of heritability (50-75\%) while harvest index found low heritability in experiment I. High estimates of broad sense heritability ( $>75 \%$ ) was recorded for all the characters except harvest index which showed moderate estimates of heritability in experiment II. It was also observed that the estimates of genotypic correlation coefficient were higher than the corresponding phenotypic correlations. The highest positive direct effect on grain yield per plant was exerted by biological yield per plant (1.021) and harvest index $(0.220)$ the direct effects of remaining characters in both the directions were too low to be considered important in experiment 1 (table1). The highest positive direct effect on grain yield per plant were exerted by biological yield per plant (0.870) and harvest index (0.224). The direct effect of remaining characters in both the directions were too low to be considered important in experiment II (table 2). The estimates of sca variances were higher than the corresponding estimates of gca variances for all the traits indicating presence of non-additive gene action. The lines, NDRK 50057 (24.06), CSR 36 (23.70), NDRK 50045 (17.96), jaya (17.36), IRRI 123 (13.20), NDRK 50051 (11.85) and Narendra 2064 (6.19) exhibited significant and positive gca effects for grain per panicle. The lines, CSR 36 (2.23), jaya (1.89), NDRK 50045 (1.82), NDRK 50057 (1.48), IT 12T 193 (1.17) and IRRI 123 (1.03) recorded significant and positive gca effects for harvest index. The six lines, CSR 36 (4.32), NDRK 50057 (4.24), NDRK 50045 (3081), IRRI 123 (2.98), Jaya (1.97) and NDRK 50057 (4.24), NDRK 50051 (1.60), possessed highly significant and positive gca effects for grain yield per plant. As early flowering being desirable, the negative and significant estimates of sca effects were considered as desirable for crosses. The negative and significant estimates of sca effects for days to $50 \%$ flowering were exhibited by six crosses. Seven crosses possessed negative and significant sca effects for plant height. Short stature in case of rice was considered as desirable. The positive and significant sca effects exhibited by 20 crosses. For 1000 grain weight the positive and significant sca effects were exhibited by 10 hybrids. 14 out of 60 crosses is emerged with positive and significant sca effects for grain yield per plant. The maximum contribution female (lines) was recorded for days to $50 \%$ flowering (85.13\%). Maximum contribution of male (testers) was recorded for biological yield per plant. The high yielding lines discussed above having high mean performance for grain yield and for several other characters may be recommended for use as tester for developing high yielding rice hybrids in target environment that is salt affected soil (Pires et al., 2015). The success of selection in improving plant characters depends mainly on presence of substantial 
genetic variability (Mall et al., 2005) and nature of heritability and gene action (Verma et al., 2003). In experiment 1 the action estimates of genotype and phenotype coefficient of variation and High heritability in broad sense along with high genetic advance in percent of mean were recorded for biological yield per plant while L:B ratio should high estimates of another phenotypic coefficient of variation and high heritability in broad sense along with high genetic advance in percent of mean and showed moderate estimates of genotypic coefficient of variation. In experiment 2 the high estimates of genotypic and phenotypic coefficient of variation and high heritability in broad sense along with genetic advance in percent of mean where recorded for panicle bearing tillers for plant biological and and grain yield per plant while and L:B ratio should high estimates of phenotyping coefficients of variations and high heritability in Broad sense along with high genetic advance in percent of mean and showed moderate estimates of genotypic coefficient of variation. The genetic architecture of green field in rice as well as other crops is based on the balance on overall net effect produced by various yield component directly or indirectly by interacting with one another. The physiological trait biological yield per plant recorded positive and significant correlation with harvest index. Selection will be quiet efficient in improving yield and yield components. Path Coefficient analysis is a tool to partition the observed correlation Coefficient into direct and indirect effects of yield components on grain yield. Path Coefficient analysis was carried out using correlation Coefficient between 13 characters (table 1) the high positive direct effects on grain yield per plant were exerted by biological yield per plant and harvest index in both the experiment. In the present study path analysis identified biological yield per plant and harvest index as most important direct as well as indirect yield and contributing traits or components which merit due consideration at time of devising selection strategy aimed at developing high yielding varieties/ hybrid in rice under salt affected soil. The present study therefore aims to study the combining ability of parents and crosses and gene action for grain yield per plant and its components by line $\mathrm{x}$ tester technique. The estimates of a sca variance were higher than the corresponding estimates of GCA variances for all the traits. The value of average degree of dominance where more than the unity $(>1)$ revealing over dominance for all the characters.

The predominance of non additive gene effects representing in unfixable dominance and epistasis components of genetic variance indicated that maintenance of heterozygosity which would be highly fruitful for improving the characters and additive gene effects may also be exploited to some extent for improving the characters by restoring to breeding method such as by parental mating followed by recurrent selection and population improvement methods. The significant and positive gca effects for yield per plant were exhibited by CSR 36, NDRK 50057, NDRK 50045, IRRI 123, Jaya, NDRK 50051, among lines and NDR 359 and Narendra Usar 2009 among testers. The crosses Narendra 3112-1 X Narendra Usar 3 having highest positive and significant sca effects in desirable direction for plant height spikelets per panicle, grains per panicle and biological yield per plant. sca effects of the crosses may not be directly related to their per se performance. The presence of high heterosis for economically important characters is useful for developing hybrid through exploitation of heterosis in present study the estimates of heterosis over better parent and standard variety (CSR 43 and IR 28) were calculated for $60 \mathrm{~F} 1 \mathrm{~S}$ to assess the genetic potential as building material in Salt affected soil. 
Table.1 Analysis of Variance for Randomised Block Design for 13 Characters in rice under salt affected soil in experiment 1

\begin{tabular}{|c|c|c|c|}
\hline Characters & \multicolumn{3}{|c|}{ Source of variation } \\
\hline d.f & Replication & Treatments & Errors \\
\hline Days to 50\% flowering & 2 & 31 & 62 \\
\hline Plant height (cm) & 0.32 & $76.16^{* *}$ & 1.02 \\
\hline Flag leaf area (cm^) & 12.45 & $145.55^{* *}$ & 7.11 \\
\hline Panicle bearing tillers per & 0.57 & $18.72^{* *}$ & 1.12 \\
\hline plant & 1.71 & $3.30^{* *}$ & 0.69 \\
\hline Panicle length (cm) & 0.39 & & 0.99 \\
\hline Spikelets per panicles & 30.19 & $1336.95^{* *}$ & 19.37 \\
\hline Grains per panicles & 32.28 & $874.71^{* *}$ & 19.46 \\
\hline Spikeletsfertility (\%) & 2.08 & $62.31^{* *}$ & 2.86 \\
\hline Biological yield per plant (g) & 1.03 & $155.50^{* *}$ & 1.41 \\
\hline Harvest index (\%) & 3.47 & $6.58^{* *}$ & 2.43 \\
\hline L:B RATIO & 0.04 & $1.27 * *$ & 0.03 \\
\hline 1000- grains weight (g) & 1.23 & $5.82^{* *}$ & 0.50 \\
\hline Grains yield per plant (g) & 0.97 & $20.68^{* *}$ & 0.87 \\
\hline
\end{tabular}

*,** significant at $5 \%$ and $1 \%$ probability levels, respectively.

Table.2 Analysis of Variance for Randomised Block Design for 13 Characters in rice under salt affected soil in experiment II

\begin{tabular}{|c|c|c|c|}
\hline Characters & \multicolumn{3}{|c|}{ Sources of variation } \\
\hline & Replication & Treatment & Errors \\
\hline d.f & 2 & 82 & 164 \\
\hline Days to 50\% flowering & 0.02 & $92.68^{* *}$ & 1.01 \\
\hline Plant height & 0.83 & $136.28^{* *}$ & 3.83 \\
\hline Flag leaf area (cm^2) & 0.84 & $20.30^{* *}$ & 1.11 \\
\hline Panicle bearing tillers per plant & 0.11 & $11.01^{* *}$ & 0.74 \\
\hline Panicle length & 0.77 & $11.08^{* *}$ & 0.76 \\
\hline Spikelets per panile & 44.98 & $1380.94^{* *}$ & 26.12 \\
\hline Grains per panicle & 8.31 & $1177.01 * *$ & 19.82 \\
\hline Spikelets fertility & 5.75 & $28.30^{* *}$ & 2.22 \\
\hline Biological yield per plant (g) & 0.21 & $167.43^{* *}$ & 2.00 \\
\hline Harvest index (\%) & 0.10 & $10.81^{* *}$ & 1.77 \\
\hline L:B RATIO & 0.05 & $1.22^{* *}$ & 0.09 \\
\hline 1000-grains weight (g) & 0.38 & $6.19^{* *}$ & 0.44 \\
\hline Grains yield per plant (g) & 0.09 & $34.72^{* *}$ & 0.96 \\
\hline
\end{tabular}


Fig.1

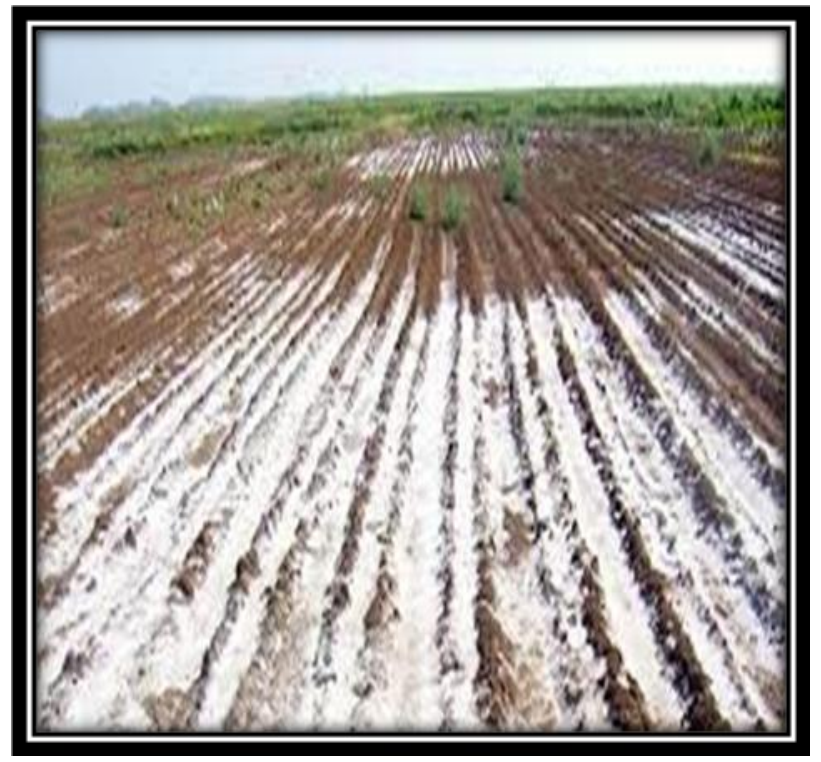

Fig.2

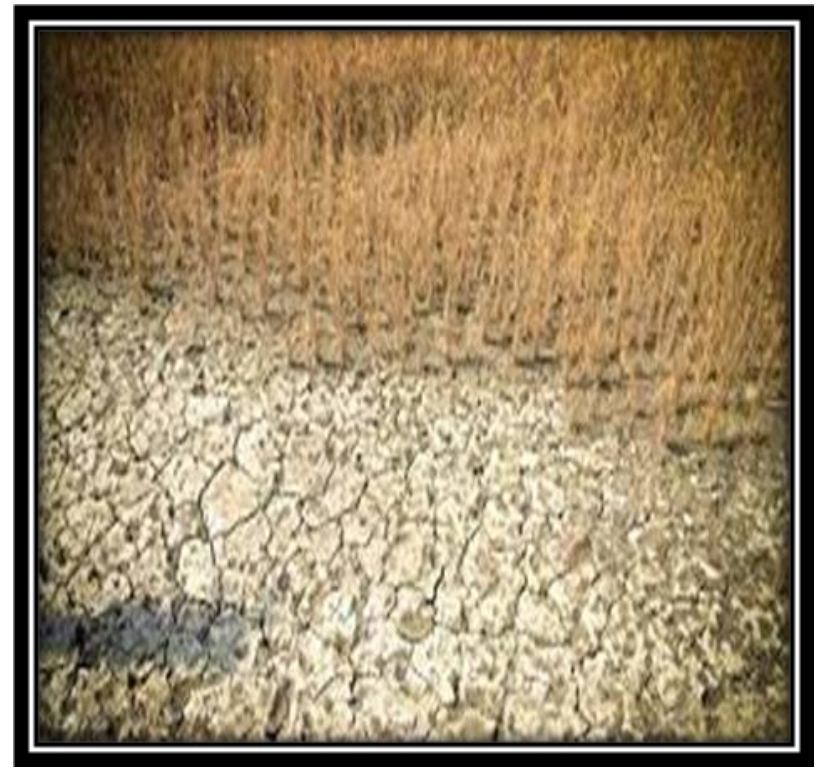

Besides yield substantial heterosis (Vidyachandra et al., 1999) over better parent and standard varieties was also observed in negative as well as in positive direction for remaining characters. While selecting the best hybrid besides the heterotic response over better parent the main performance of the crosses should also be given due consideration.
The combining ability experiment was based on evaluation of a line $\mathrm{x}$ tester set of 60 hybrids (F1s) and their twenty three parents for thirteen characters under the salt affected soil in randomised block design with three replications during Kharif, 2015. In general PCV where higher than the GCV (Manna et al., 2006) for all the characters under salt affected in both the experiments which 
indicates the influence of environment. These four traits in experiment 1 and 8 traits in experiment 2 emerged as most important associates of grain yield per plant under salt affected soil path analysis identified biological yield in plant and harvest index as most important direct yield (Malini et al., 2006) contributing traits in both the experiments. The estimates of sca a variance where higher than the corresponding estimates of GCA variance for all the characters indicating predominance of non additive gene action. The contribution of lines was maximum for days to $50 \%$ flowering followed by panicle length, plant height, spikelets fertility and L:B ratio.

Molecular breeding proved to be useful tool for development of salt tolerant cultivar. GWAS (genome wide association study) by identification of candidate genes (Yuan et al., 2020) e.g. Os STL1 and Os STL2. Similarly molecular breeding help for discovering certain regulators e.g. RGA1 helpful in salt tolerant mechanism. (Peng et al., 2019)

\section{Acknowledgement}

The authors wish to thank Dr(Prof) Shailendar Sharma, Head of department (Genetic and plant breeding), CCS University, Meerut for his valuable help throught the course of this work for providing many useful discussions. Also thank Deepak jee (Mahuli, Patna) for the data analysis and Khushikumari (Patna) for help in providing format of research paper.

\section{References}

Arunachalam, V.(1974) the fallacy behind the use of modified line $\mathrm{x}$ tester design. Indian j.Genet, 34 (2) : 200-207

Krishna, L; Raju, Ch. D: Surender Raju, Ch; Vanisree, S. Reddy, P. N. And Reddy B.B (2011) heterosis for yield and quality traits in rice (Oryza sativa L.).
Madras Agric. J., 98 (4-6): 109-112

Krishnamurthy, H. T. and Kumar, H. D. M. (2012). Correlation and path coefficient studies of some physiological traits among indigenous aromatic rice (Oryza sativa L) cutivars Agricultural\& Biological Research, 28 (2):120-127.

Krishnamurthy, H. T. and Kumar, H. D. M. (2012). Genetic variability for character association for kernel and quality traits in indigenous aromatic rice (Oryza sativa L) cultivars. Agricultural \& Biological Research, 28 (2): 112-114

Mahto, R. N Yadava, M. S. and Mohan, K. S. (2003). Genetic variation, character association and path analysis in rainfed upland rice. J. Dryland Agric. Res. and Devel., 18 (2):196-198.

Malini, N Sundaram, T; Hari, S.; Ramakrishnan and Saravanan, $\mathrm{S}$. (2006). Genetic interpretation of yield related traits in rice (Oryza sativa L). Research Journal of Agriculture and Biological Sciences, 2 (4): 153155.C.2000).

Mall, A. K.; Babu, JD. P. and Babu, G S. (2005). Estimation of genetic variability in rice. Maharashtra Agric Univ, 30 (2): 166-168.

Manna, M. Al N. M. D. and Sasmal, B. G. (2006). Variability, correlation and path-coefficient analysis in some important traits of lowland rice. Crop Res., 31 (1): 153-156.

Peng, P, ;Gao, Y. D.; Li, Z., Yu, Y. W.; Qin, H.; Guo, Y.; Huang, R. F.; Wang, J.(2019) Proteimic analysis of a rice mutantsd58 possessing a novel $\mathrm{d} 1$ allele of heterotrimeric $\mathrm{G}$ protein alpha subunit (RGA1) in salt stress with a focus on ROS scavenging. Int. J. Mol. Sci. 20,167.

Pires P S, Negra S, Oliveira M M, Purugganan M D. (2015). Comprehensive 
phenotypic analysis of rice (Oryza sativa L.) response to salinity stress. Physiologiaplantarum155:43-54.

Prasad R. K, Suneetha, Y. and Srinivas, T. (2019). Studies on heterosis and combining ability in rice (Oryza sativa. L.) Int. J. Agric. Sci., 15:60-66.

Satya, A.; Kandasamy, G. and Ramalingam, J. (1999). Heterosis in hybrid rice.(Oryza sativa L.). Crop Res, 18 (2): 243-246.

Shama Parveen, Singh and P. K. (2019). Exploitation of heterosis for quality traits in rice (Oryza sativa L.) using CMS system under upland conditions. Int. J. Current. Microbiology. App. Sci., 8:126-134.

Verma, O. P., Santoshi, U. S. And Srivastava,
H. K. (2003), Governance of gene action and combining ability for certain grain quality traits in three diverse rice (Oryza sativa. L.) growing ecosystems. Jour. of Sustainable Agriculture, 22(4):63-78

Vidyachandra, S., B; Shridhara, S. and Chilkkalingaiah. (1999). Heterosis breeding in rice for higher yields. Mysore J. Agric. Scl, 33(4): 328-332.

Yuan, J.; Wang, X.; Zhao, Y.; Khan, N. U.; Zhao, Z.; Zhang, Y.; Wen, X.; Tang, F.; Wang, F.; Li, Z. (2020) Genetic basis and identification of candidate genes for salt tolerance in rice by GWAS. Sci. Rep. 10, 9958.

\section{How to cite this article:}

Raushan Lal, O. P. Verma, Manoj Kumar, Neeta Tripathi and Sharan, A. K. 2021. Genetic Architecture for Yield and Contributing Components in Rice (Oryza sativa L.) under Salt Affected Soil. Int.J.Curr.Microbiol.App.Sci. 10(07): 681-688.

doi: https://doi.org/10.20546/ijcmas.2021.1007.074 